\title{
Türkiye’de Girişimcilik ve Türk Girişimci Profili Üzerine Bir Analiz
}

\author{
Yrd. Doç. Dr. Asuman SÖNMEZ* \\ T.C. İstanbul Kültür Üniversitesi, İI.I.B.F., İsletme Bölümü, İSTANBUL \\ Araş. Gör. Andaç TOKSOY \\ T.C. İstanbul Kültür Üniversitesi, İI.I.B.F., İsletme Bölümü, İSTANBUL
}

\begin{abstract}
$\ddot{O Z E T}$
Girișimcilik ve yeni girișimciler tüm dünyada ekonomilerin gelişmesi ve işsizliğin önüne geçilmesi konularında çıklş yolu olarak görülmektedir. Türkiye ekonomisi açısından da yeni girişimlerle yaratılacak üretim ve istihdam artışı büyük önem arz etmektedir. Girişimciliğin yaygınlaşması ve bilinçli girişimcilerin sektörlerde yerlerini alabilmeleri için son ylllarda gerek devlet gerek özel sektör çalışmalarının hızla arttı̆̆ görülmektedir. Sektörler arası işbirliğinin gelişmesine de katkıda bulunan girişimcilik üzerine çalışmalar giderek ülke genelinde yaygınlaşmaktadır. Türkiye'de gerçekleşen girişimcilik konusundaki atılımların saptandiğı ve Türk girişimci profilinin analiz edildiği çalışmanın amacl; özellikle girişimcilerin demografik özellikleri, faaliyet göstermek istedikleri sektörler, finansmana yönelik ihtiyaçları gibi konuların analizidir. Söz

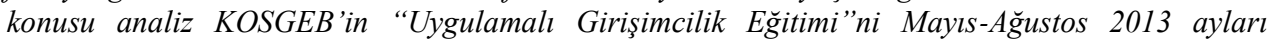
arasında tamamlayan 400 kişilik girişimci adayı grubunun verdikleri bilgiler dahilinde yapılmış, yöntem olarak frekans dă̆ılımı kullanılmıştır.
\end{abstract}

Anahtar Kelimeler: Girişimcilik, girişimci

JEL Sinıflaması: L26, M13

\section{Entrepreneurship in Turkey and An Analysis on Turkish Entrepreneur Profile}

ABSTRACT

Entrepreneurship and entrepreneurs are described as an exit from economic turmoil for the economies in whole world in respect of development of economies and decreasing unemployment problems. Increase in production and employment thanks to new entrepreneurs has great importance in respect of Turkish economy as well. Therefore in order to develop entrepreneurship culture and activities and creating new entrepreneurs for different sectors, both state and private institutions in Turkey have been begun to increase their operations rapidly for the recent years. Works on entrepreneurship which also contribute inter-sectoral relations becomes popular country-wide in Turkey. This study which stated entrepreneurship activities in Turkey for recent years and explored Turkish entrepreneur profile aims to analyze to the subjects such as their demographic features, sectors, capital needs. The mentioned analysis performed with data of 400 people attended to "Applied Entrepreneurship Training" of Republic of Turkey Small and Medium Enterprises Development Organization's (KOSGEB) between May and August 2013 by using frequency analysis technique.

Key Words: Entrepreneurship, entrepreneur

JEL Classification: L26, M13

\footnotetext{
* Bu çalışma yazarın TÜBİTAK 2219-Uluslararası Doktora Sonrası Araştırma Bursu kapsamında Wayne State Üniversitesi'ndeki post-doktora araştırmaları sırasında hazırlanmıştır. Aynı zamanda KOSGEB' in "Uygulamalı Girişimcilik Eğitimleri” tanımlı danışmanı olarak görev yapmaktadır.
} 


\section{GİRIŞ}

Dünya ekonomisinin gelişmesi ve 2007 yılından beri yaşanan ve zaman zaman belirli bölgelerde etkisini hala sürdüren finansal krizden çıkış yolu olarak girişimcilik ve yeni girişimciler gösterilmektedir. Ticaretin gelişebilmesinde de girişimcilerin önemli bir yeri vardır. Tüm dünyada ülkelerinde olduğu gibi Türkiye'de de girişimcilik konusunun ekonomi üzerindeki etkisi kavranmış ve farklı açılardan yaklaşımlarla girişimcilerin önlerindeki engellerin kaldırılması ve girişim sayısının artması için çalışmalar yapılmış ve yapılmaktadır.

Bu çalışmada; Türkiye'de girişimciliğin gelişimi, son yıllarda kamu ve özel sector kuruluşları tarafından geliştirilen ve uygulanan programlar açıklanmış, 400 girişimci adayı üzerinden yapılan bir araştırma çalışması ile Türk girişimci profilinin analiz edilmesi amaçlanmıştır. Çalışmanın analiz aşamasında yöntem olarak frekans dağılımı yöntemi kullanılmıştır.

\section{LITERATÜR}

Girişimcilik ve girişimciler katma değer yaratma, istihdam yaratma, sektörler arası ilişkileri kuvvetlendirme, sosyal fayda ve fakirlikle mücadele, dengeli gelir dağılımın sağlanmasına yardımcı olmaları gibi özelliklerinden dolayı her ülke ekonomisinin gelişiminde önemli bir role sahiptir.

Orta Çağ'da girişimci büyük ölçekli üretim projelerini yöneten bir aktör ya da yönetici olarak benimsenmiştir. $O$ dönemde girişimci risk almamakta, sadece tahsis edilen kaynakları kullanarak projeyi yöneten kişidir. 17.yy'da ise girişimcilik kavramı ile risk arasında ilk kez ilişki kurulmaya başlanmış, girişimci kar ve zarar etme riskini üstlenerek, devletle anlaşma imzalamak suretiyle mal ve hizmet tedarikinde bulunan kişi olarak tanımlanmıştır. Girişimcilik kelimesi ilk olarak ekonomi literatüründe 1730'lu yıllarda Fransız Richard Cantillon tarafından kullanılmış, John Stuart ise 19. yy'da İngiliz literatürüne sokmuştur (Çetindamar, 2002: 33).

Şekil 1. Girişimcilik Kavramının Tarihsel Gelişimi

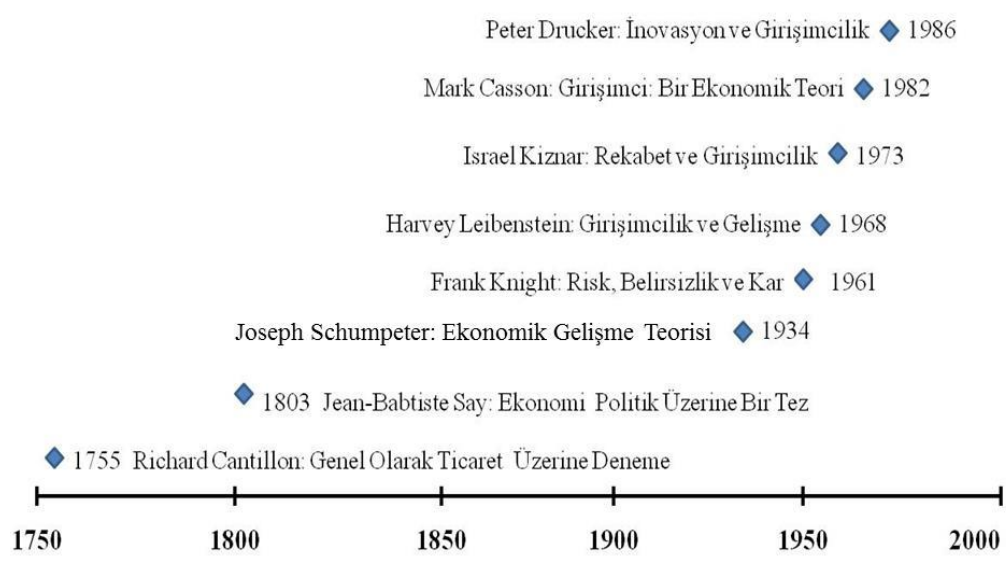

Kaynak: www.wikipedia.org 
Fransız Merkantilizmi'nin öncülerinden Cantillon girişimciye sermaye bulma özelliğinin yanı sıra risk üstlenen kişi özelliğini de eklemiştir. Girişimcilik kavramında önemli çalışmaların gösterildiği "Genel Olarak Ticaret Üzerine Deneme" isimli eseri 1955 yılında Fransızca'ya çevrilmiştir. Beaudeau girişimci, risk üstlenen, planlayan, idare eden, organize eden ve sahip olan kişi olarak açıklarken, Jean Baptiste Say sermayenin karı ile girişimcinin karını ayırt etmiştir. Francis Walker, girişimcilik konusuna yönetim becerisini de ekleyerek sözkonusu beceriden yarar sağlayan ve geçerli faiz ve para miktarı arasında seçim yapan olarak tanımı genişletmiştir. Joseph Schumpeter girişimciyi yenilikçi ve denenmemiş teknolojiyi geliştiren yani inovatif yeniliklere öncülük eden kişi olarak tanımlamıştır. Girişimciler bu yapıları ile çalıştıkları firmalarına gelişme getirdikleri gibi ekonomik gelişmeye de katkıda bulunurlarken inovatif aktiviteler beş farklı yeni bileşim şeklinde açıklanabilir (Schumpeter, 1963 (1911) :66). Bunlar; henüz tüketicilerin bilmedikleri yeni ürünlerin tanıtımı, üreticilerin henüz kullanmadıkları yeni teknolojilerin tanıtımı, girilmemiş ya da bilinmeyen bir pazara açılma, ilk defa üretilecek ya da kullanılacak yeni hammadde ve/veya yarı mamullerin çıkışı, tekel durumunu yaratmak ya da kırmak için endüstrilerin yeniden organizasyon şeklinde özetlenebilir. Peter Drucker'a göre inovasyonun yanı sıra girişimci firsatları maksimize eden kişidir. Albert Shapero girişimciyi teşebbüs eden, inisiyatif alan, bazı sosyal ve ekonomik mekanizmaları organize eden ve iflas riskini göze alan kişi olarak tanımlamıştır. Robert Hiscrich ise girişimci ve girişim finansal, sosyal ve psikolojik risklerle birlikte parasal ve kişisel tatmin alan; bu amaçla gerekli zaman ve çabayı harcayarak farklı bir değere sahip bir şey yaratma sürecidir. Kirzner girişimciye yeni ekonomik sosyolojik perspektiften bakmış, girişimci ile pazar ve tüketici ilişkisi üzerine odaklanmıştır.

Başarılı girişimcilerin paylaştıkları ortak karakterleri azim, tutku, belirsizliklere karşı hoşgörülü olma, vizyon sahibi olma, kendine inanma ve güvenme, esneklik, yeni kurallar yaratma şeklinde yedi başlıkta toplamak mümkündür. "Beş Önemli Karakter Özelliği ve Girişim Durumu" başlıklı 23 yayınlanmış eser üzerinden yapılan araştırma girişimcilerin kurumsal yöneticilerden daha farklı kişiliklerde olduklarını, açılık ve deneyim (merak ve inovasyon), dürüstlük ve vicdan (disiplin ve motivasyon) konularında daha yüksek değerlere sahip olduklarını saptamıştır (Robinson, 2014). Girişimcilerin sahip olmaları gereken dört önemli yetenek ise iş yetenekleri, kişisel yetenekler, liderlik yeteneği ve girişimcilik yeteneği olmak üzere sıralanabilir. 
Şekil 2. Girişimcilikte Dört Önemli Yetenek

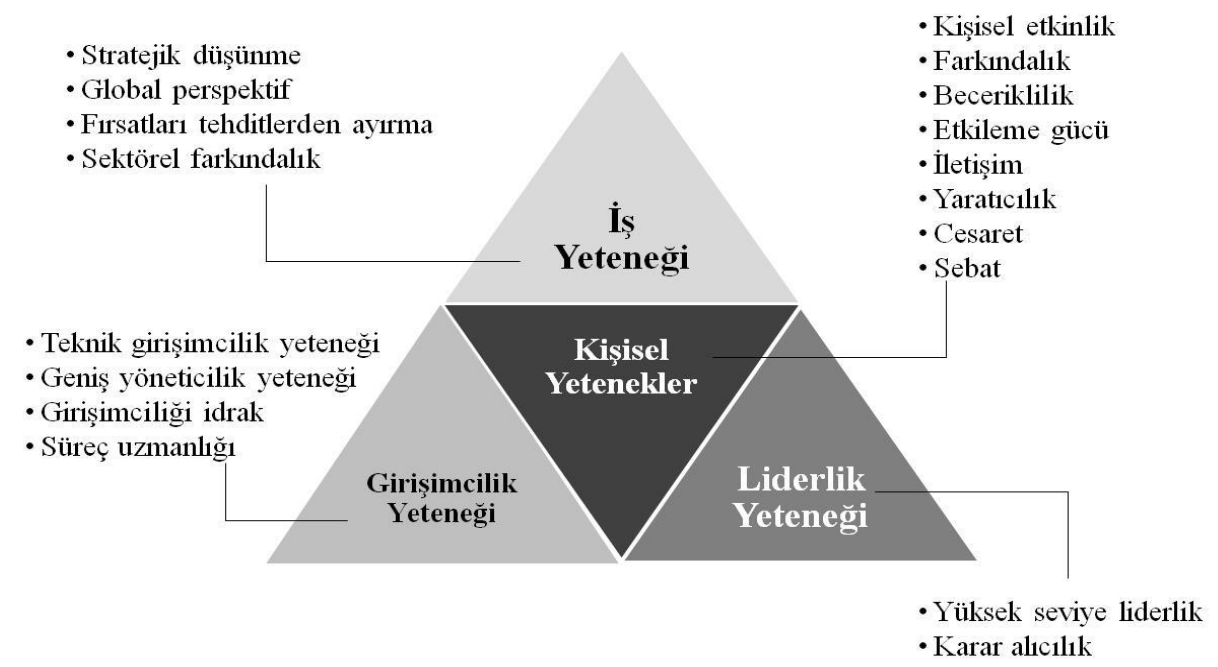

Kaynak: http://turtleinvestor888.blogspot.com/2009/07/entrepreneurship-requires-four-areasof.html

Girişim konusuna bakılmaksızın bir girişimcinin sahip olması gereken üç özellik hedeflediği alanda başarılı olmaya yönelik motivasyona sahip olma, risk alma ve yenilikçi olma, girişilen alanla ilgili olarak bilgi sahibi olma şeklinde ifade edilebilir. Bu nitelikleri teknik, yönetsel ve bireysel olarak tasnifleyen Hisrich'e göre bu özellikler aşağıdaki tabloda yer almaktadır.

Tablo 1. Girişimcinin Özellikleri

\begin{tabular}{l|ll}
\hline Teknik Beceriler & Yönetsel Beceriler & Bireysel Beceriler \\
\hline Sözlü iletişim & Amaçları belirleme & İsel denetim \\
Çevresel gözlem & Karar verme & Risk alma \\
Teknik yönetim bilgisi & İnsan ilişkileri & Yenilik yapma \\
Teknoloji & Pazarlama & Değişimi yönetmek \\
Kişilerarası ilişki & Finans & Karalı olma \\
Dinleyici olma & Muhasebe & Vizyon sahibi olma \\
Örgütleme & Yönetim-Yönetim geliştirme & \\
Şebeke kurabilme & Denetim & \\
Yönetim türü & Sorun çözme & \\
Takım oyuncusu olma & Girişim & \\
\hline
\end{tabular}

Kaynak: Hiscrich, 1998: 20

Özetle; genel olarak bir girişimcide bulunması istenen özellikler, risk alabilme yeteneği, başarılı olma isteği, başkalarıyla çalışabilme, onlara güvenebilme ve onları yönetebilme eksikliklerini kabul edebilme ve araştırmacı olma, zor ve ağır şartlar altında çalışabilme ve sabırlı olma şeklinde sıralanabilir. 


\section{TÜRKIYYE'DE GİRIŞIMCIILIĞİN GELISŞIMII}

Türkiye'de finansal liberalizasyon hareketlerinin öncesindeki kapalı ekonomik model ve ekonomide geçerli olan ithal ikamesi uygulaması, iş dünyasını global rekabet ortamından uzak tutarak, iç piyasada hakim olmanın verdiği rehavetle karlarını korumaya çalışan ve siyasi ve ekonomik belirsizlikler içinde risk almaktan çekinen bir ortam yaratmıştır. Günümüzde ise her geçen gün küçülen dünya ve sınırların ortadan kalktığı ekonomik sistemde rekabetten uzak durabilmek neredeyse hiçbir işletme ya da sektör için imkan dahilinde değildir. Söz konusu gelişmeler Türkiye ekonomisi için de geçerli olup, son yıllarda girişimciliğin önemi kavranmış ve gerek devlet gerekse özel sektör kuruluşlarının katkılarıyla, girişimcilik konusunda yeni çalışmalar yapılmaya başlanmıştır.

Girişimlerin başarısı ve devamlılığı sürekli tartışılan bir konu olup, başarının önündeki engeller saptanmaya çalışılmakta ve ortadan kaldırılması için politikalar üretilmektedir. Açılan her işletmenin başarılı olacağı ve uzun yıllar faaliyetlerine devam edeceğini beklemek mümkün değildir. Dünyanın en gelişmiş ekonomileri arasında ilk sıralarda yer alan ve birçok farklı finansal araçla işletmeler için alternatif finansman modelleri üreten Amerika Birleşik Devletleri'nde (ABD) bile girişimler uzun ömürlü değildir.

Şekil 3. ABD’deki Girişimcilerin Gelişimi

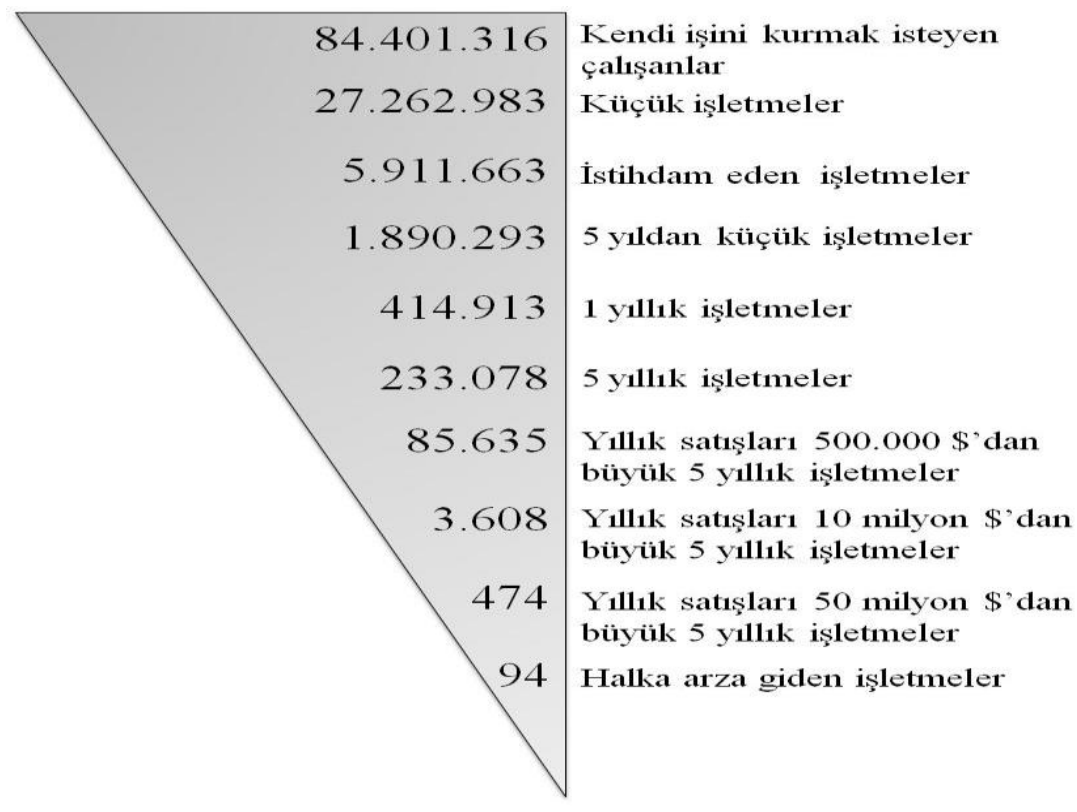

Kaynak: Shane (2011), U.S. Census Bureu, Gallup/Eurobarometer 
Söz konusu duruma neden olarak öncelikle satışlardaki yetersizlikler, ardından rekabette zayıflık, beklenmedik harcamalar ve alacakların tahsilatında zorluklar gösterilmektedir (Berry, 2007http://timberry.bplans.com/2007/06/market-fitis-c.html).

Benzer gelişim şekli ve aynı sorunlar Türkiye'deki girişimciler için de geçerlidir. Türkiye'de tam zamanlı bir işte çalışanlar içinde girişimcilik hakkında olumlu görüş belirtenlerin oranı yüzde 76'dır (GfK, 2011). 2010 yılında toplam istihdam içerisinde işveren olarak çalışanların payı yüzde 5.3 seviyesindedir (TÜIK, 2013). Finansal kaynaklara erişim konusu ise yine hem Türk hem de dünyanın bir çok ülkesinde gerek girişimciler gerekse mikro, küçük ve orta ölçekli işletmeler açısından önemli sorun olarak tanımlanmaktadır.

Diğer taraftan kurulan şirket kapanan şirket istatistiklerinde Grafik 1'de de gösterildiği üzere son yıllarda kapanan şirket sayısında artış kaydedilmiştir. Bu durum şirketlerin son dönemde ekonomik ve siyasi krizlerin de etkisiyle ayakta kalmakta zorlandıklarının bir göstergesidir. Söz konusu istikrarsızlıkların olduğu dönemlerde girişimcilerin şirket kurmakta da istekli olmadıkları görülmektedir.

Grafik 1. Kurulan Şirket Kapanan Şirket İstatistikleri

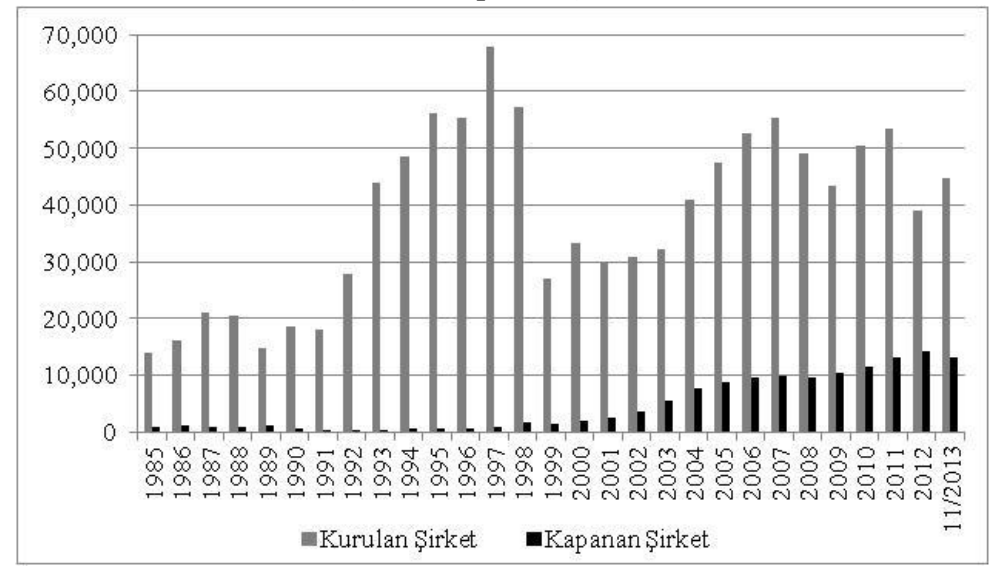

Kaynak: TÜİK, TOBB

2001 y1lı Global Entrepreneurship Monitor - Küresel Girişimcilik Raporu (GEM)'na göre uluslar arası girişimcilik endeksinde kullanılan 100 yetişkin içinde şirket kuran insanların sayısında Türkiye 29 ülkeden daha az sayıda girişimciye sahip olup, şirket kuran sayısı Meksika'da 18,7, İrlanda'da 12 ve ABD'nde 11,7 iken Türkiye'de bu say1 4,6 kişi olarak belirlenmiştir (TÜSİAD, 2003; 8). 2012 yılında 69 ülkeden 198.000 kişi ile yapılan anket sonucunda oluşturulan aynı raporda ise Türkiye'nin 2006 yılında yüzde 6.11 olan girişimcilik notu yüzde 12.22 'ye yükselmiş, erken girişimcilik indeksi açısından araştırmaya katılan 30 etkinlik güdümlü ekonomi arasında Türkiye 17. sırada yer almışıtır. Benzer şekilde kurumsallaşmış girişimcilerin 18-64 yaş arasındaki yetişkin nüfusa olan oranı, 2006 yılında yüzde 2.2, 2008 yılında yüzde 4.6 iken 2010 yılında yüzde 10.7'ye yükselmiştir ("Türkiye'de Yükselen Değer Girişimcilik", 2011). Şirketlerini kurma aşamasında olan girişimcilerin oranı ise 2006 yılında 
yüzde 2.2, 2008 yılında yüzde 3.2, 2011 y1lında 3.7 iken 2012 y1lında yüzde 7.25 'e çıkmıştır. Söz konusu istatistikler Türkiye'nin girişimcilik konusunda yaptığı çalışmaların başarılı bir şekilde ilerlediğinin göstergesidir.

Kadın girişimcilik oranlarında ise rakamlar yükselmekle birlikte, istenen seviyelere henüz gelinememiş olup, 2010 y1lı verilerine göre toplam işveren olarak çalışanlar içinde kadının payı yüzde 6.9 iken erkeğin payı ise yüzde 93.1'dir (TÜIKK, 2013). 2011 yılında her 100 erkeğe karşılık 28 kadın girişimcilik faaliyetinde bulunmuştur ("Türkiye'de Yükselen Değer Girişimcilik", 2011). Yapılan bir araştırmada ise kadınların yüzde 39'unun girişimciliğe olumlu baktığı, girişimcilik konusunda yüzde 42 ile en cesur kadınların bulunduğu İsviçre'den sonra Türkiye'nin yüzde 41 ile ikinci sırada yerini aldığı belirtilmiştir (GfK, 2011). Kadınların iş hayatına girmesinin önünün açılması hedefiyle KOSGEB'in “Girişimcilik Desteği”nde pozitif ayrımcılık yapılmıştır. Benzer şekilde kadınların gelişimine yönelik sivil toplum kuruluşlarının da ülke çapında çeşitli faaliyetleri bulunmaktadır.

Özetle; ülke çapında girişimciliğin gelişmesi için çalışmalar, 1980'li yıllardan itibaren uygulanmaya başlanmakla birlikte, 1990'l y yllarda hız kazanmış, 2000'li yıllarda ise desteklerin ve destek sağlayan kurum/kuruluşların sayısında önemli artışlar yaşanmıştır olup, özellikle son yıllarda;

- Dokuzuncu Kalkınma Planı (2007-2013)'de girişimcilerin KOBİ'lerin ve girişimcilerin rekabet güçlerini artırmak ve yeni pazarlara açılmalarını sağlamak için, iş kurma ve iş geliştirme aşamalarında eğitim ve danışmanlık hizmeti sağlanması konusunun gündeme alınması, teknoloji geliştirme amaçlı girişimlerinin önünün açılması için risk sermayesi ve benzer araçların yaygınlaştırılması (Kalkınma Bakanlığı, 2006; 40, 76, 82)

- Onuncu Kalkınma Planı (2014-2018)'de girişimciliğin eğitim sisteminde işlenen konular içine alınması ve küçük yaşta girişimcilik kültürünün aşılanması, üniversite-sanayi işbirliğinin girişimciliği geliştirici yönde de kullanılması, akademisyen ve öğrencilerin ar-ge ve girişimcilik faaliyetlerinin desteklenmesi, sadece sanayi, hizmetler, ticaret sektörlerinde değil tarım sektöründe de girişimciliğin yaygınlaşması (Kalkınma Bakanlığı, 2013a: 35, 98-100),

- Sivil Toplum Kuruluşları ile birlikte eğitimlerin düzenlenmesinin ön görülmesi,

- Orta Vadeli Program 2013-2015'de yenilik tabanlı girişimcilik destek mekanizmalarının geliştirilmesi ve girişimciliği geliştiren kümelenme oluşumlarının desteklenmesi (Kalkınma Bakanlığı, 2012: 38), Orta Vadeli Program 2014-2016'da girişimcilerin finansman kaynaklarına erişimlerinin kolaylaştırılması (Kalkınma Bakanlığ1, 2013b: 46),

- Türkiye Sanayi Stratejisi Belgesi 2011-2014 (Avrupa Üyeliğine Doğru) Eylem Planı'nda sanayi sektöründe girişimciliğin yaygınlaştırılmasına yönelik eğitim ve desteklerin verileceğinin belirtilmesi (Bilim, Sanayi ve Teknoloji Bakanlığı 2010:22, 42), 
- KOSGEB 2011 - 2013 KOBİ Stratejisi ve Eylem Planı'nda girişimciliğin tüm topluma yayılmasının sağlanması için çalışmaların yapılacağının ifade edilmesi (KOSGEB, 2011b; 58), girişimcilik kültürünü geliştirmek ve başarılı yeni işletmelerin kurulmasını teşvik etmeyi amaç edinmesi (KOSGEB, 2013a: 13) girişimcilik politikalarına rehberlik yapmak ve kültürü yaygınlaştırmak için uygulamalarda bulunması (KOSGEB, 2011a; 9)

gibi yapılan çalışmalarla, Türkiye'de girişimcilik ve girişimciler desteklenmiş ve desteklenmeye devam edeceklerdir.

Söz konusu çalışmalar sonucunda Türkiye'nin son 2 y1l içinde girişimcilikte ciddi yollar kat etmiş olup, 2011 yılında girişimciliğe olumlu bakma ve kendi işini kurma konusunda Türkiye, İsviçre ile birlikte yüzde 50'lik oranla Avrupa'nın en cesur ülkesi konumuna gelmiştir. (GfK, 2011). Ulusal Franchising Derneği'nin verileri de söz konusu durumu desteklemekte, Amerika'da 12, Finlandiya'da 60, Almanya'da 45 kişiden biri kendi işini kurmak isterken, Türkiye'de her iki kişiden birinin kendi işini kurmak istediğini ifade etmektedir. (https://www.kobilersizinicin.com/turkiyede-girisimcilik.aspx)

\section{TÜRKIYY'NIN GÍRIŞiMCI PROFILI ANALIZİ}

Çalışmanın bu bölümünde çoğunluğu İstanbul'da yaşayan 400 girişimci adayının Mayıs - Ağustos 2013 ayları içerisinde KOSGEB, İstanbul Kültür Üniversitesi ve İŞKUR ortaklığında düzenlenen KOSGEB Uygulamalı Girişimcilik Eğitimleri'ni tamamlayan ve eğitimlere katılabilmek için doldurmuş oldukları başvuru formları üzerinden değerlendirmeler yapılmış Türk profilinin analiz edilmesi amaçlanmıştır. Yöntem olarak frekans analizi yöntemi tercih edilmiş ve benzer alanda akademik ve iş dünyası tarafından gerçekleştirilmiş çalışmalarla karşılaştırmalar yapılmıştır. Başvuru formlarından seçilen ve çalışmanın temelini oluşturan sorular aşağıdaki gibidir;

1- Cinsiyetiniz?

2- Doğum tarihiniz?

3- En son bitirdiğiniz okul hangisidir?

4- E-posta adresiniz nedir?

5- $\quad$ Ev adresiniz nedir?

6- Telefon numaranız nedir?

7- Kurmak istediğiniz iş fikri nedir?

8- İşi nerede kuracaksınız?

9- Kuracağınız iş ile ilgili deneyiminiz var mı?

10- İşin kurulumu için gereken sermaye ne kadardır?

11- Ortağınız olacak mı?

12- Daha önce kendi işinizi kurdunuz mu?

13- Çalıştıracağınız eleman olacak mı kaç kişi?

14- İşi kurarken faydalanacağınız finansal kaynaklar nelerdir?

\section{IV.A Demografik Özellikler}

400 kişilik grupta 187 kadın 213 erkek üzerinden değerlendirme yapılmıştır. Kadın erkek oranının yüzde 46.8 ve yüzde 53.2 olması Türkiye'de kadın girişimci sayısının erkek girişimci sayısına eşit olmasından ziyade eğitime 
seçilen girişimci adaylarına eşit katılım hakkının verilmek istenmesinden kaynaklanmaktadır. Bununla birlikte, KOSGEB'in "Uygulamalı Girişimcilik Eğitimleri"ne katılan kadın girişimci adayının sayısı her yıl artış göstermektedir. Benzer grup üzerinde 110 kişi ile yapılan bir analizde de eğitimlere katılan girişimci adaylarının yüzde 55'i erkek, yüzde 45'i kadındır (Toksoy ve Sönmez, 2013; 333-351). Yapılan bir araştırmaya göre ise Türkiye'de kendi işini kurmayı isteyenlerin oranı erkeklerde yüzde 63, kadınlarda ise yüzde 43'tür (GfK, 2010).

Katılımcıların yaş aralığı ise genel olarak 20 - 59 yaş arasında olup, $30-$ 44 yaş arasındaki girişimci sayısı toplam girişimci sayısının yüzde 25'ini oluşturmakta, ortalama yaş ise kadınlarda 34, erkeklerde 32'dir. Yapılan bir diğer araştırmada da kadınların yaş ortalaması 35, erkeklerin yaş ortalaması 30 ve girişimcilerin yaş ortalaması ise 31'dir. (BIC Angel Investment, 2013).

Grafik 2. Girişimcilerin Yaş Aralığı

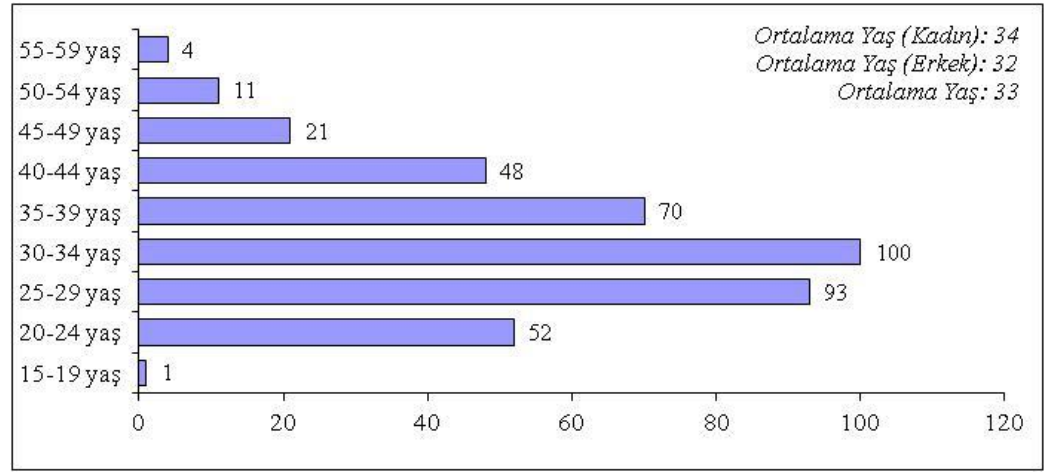

Türkiye'nin en hızlı büyüyen ilk 100 şirketini kuran kişilerin, şirketlerini kurduklarındaki ortalama yaşları 31, kurucuların şu anki yaş ortalamasının 41'dir (“Türkiye'nin En Hızlı Büyüyen 100 Şirketi açıklandı", 2013). Söz konusu veriler çerçevesinde ülkemizin genel olarak girişimcilik yaşının kadın erkek ayrımsız 30 - 44 yaş arasında olduğunu söyleyebiliriz.

Girişimci adaylarının yüzde 77.5'i İstanbul Avrupa, yüzde 18.5 'i İstanbul Anadolu ve yüzde 4'ü İstanbul dişından gelen kişilerden oluşmaktadır. Eğitimlerin İstanbul Avrupa yakasında düzenleniyor olmasının söz konusu dağılım üzerinde etkisinin olduğunu söylemek mümkündür. Girişimci adayları daha çok kendilerine yakın bölgelerde eğitime katılmayı ve iş kurmayı tercih etmektedirler. Benzer şekilde 400 girişimci adayından yüzde 91.8'inin İstanbul'da işini kurmak istemesi de yine girişimcilerin kendi şehirlerinde iş yapmak istediklerinin bir göstergesidir. Bununla birlikte, Marmara Bölgesi girişimcilik konusunda Türkiye'nin birinci bölgesi olup, bölge halkının yüzde 62'si (Türkiye ortalaması yüzde 53) kendi işini kurabileceğini düşünmektedir (GfK, 2010).

Girişimci adaylarının eğitim seviyeleri genel olarak Türkiye ortalaması olan 6 yıl eğitim süresinin yaklaşık iki katına denk gelmektedir. Grafik 3'ün de gösterdiği gibi 400 kişinin yüzde 57.3'ünü üniversite mezunu katılımcılar oluşturmaktadır. 
Grafik 3. Girişimcilerin Eğitim Seviyesi

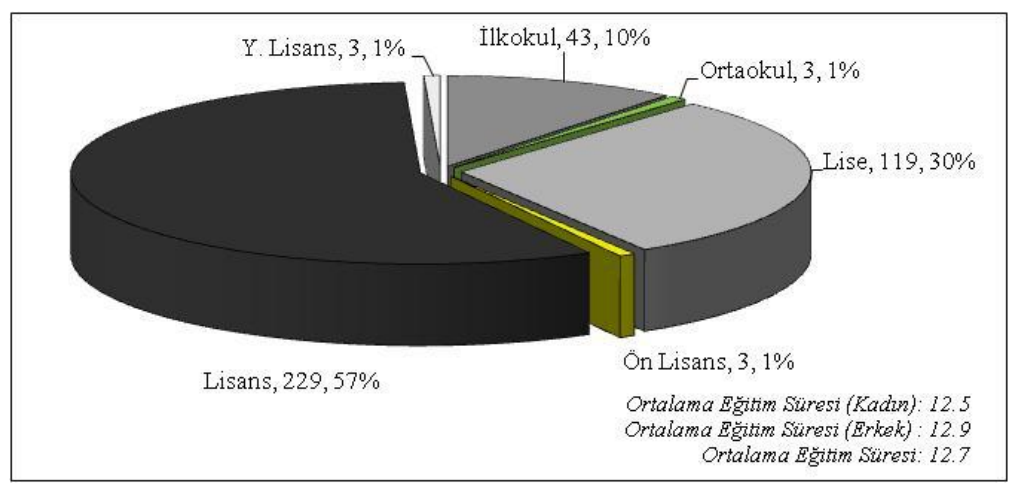

Eğitim seviyesindeki yükseklik çalışmayı oluşturan soruların daha bilinçli bir grup tarafından cevaplandırıldı̆̆ını göstermesi açısından önemlidir.

\section{IV.B. İş Fikri ve Girişimlerin Sektörel Dağılımı}

KOSGEB'in 2009 yılı verilerine göre Türkiye'deki yaklaşık toplam 3.2 milyon KOBİ'nin sektörel dağılımı; yüzde 82'i ticaret ve hizmetler, yüzde 13'ü ise üretim sektörü şeklindedir. 2010 yılı verilerine göre ise girişimcilerin en fazla faaliyet gösterdiği ilk üç sırada yüzde 40.5 ile toptan ve perakende ticaret; motorlu kara taşıtlarının ve motosikletlerin onarımı, yüzde 17.7 ile ulaştırma ve depolama, yüzde 12.9 ile imalat sanayi yer almıştır (TÜİK, 2013). KOSGEB'e kayıtlı işletmelerde ise söz konusu oranlar sırasıyla yüzde 42.4, yüzde 7.6 ve yüzde 21.7'dir (KOSGEB, 2011a: 41)

400 girişimci adayının işlerini kurmayı hedefledikleri ana sektörlerde de yine ağırlık hizmet ve ticaret sektörlerindedir. Grafik 4'ün de gösterdiği gibi sonuçlar Türkiye dağılımına uygun olarak şekillenmiş olup, girişimci adaylarının daha çok hizmet ve ticaret sektörlerinde (toplam yüzde 77) faaliyet göstermek istedikleri görülmektedir. İstihdam ve özellikle katma değer yaratımı açısından önemli sektör olan üretim sektörünün payı ise yüzde 23'tür.

Grafik 4. Girişimcilerin İş Kurmayı Planladıkları Sektörler

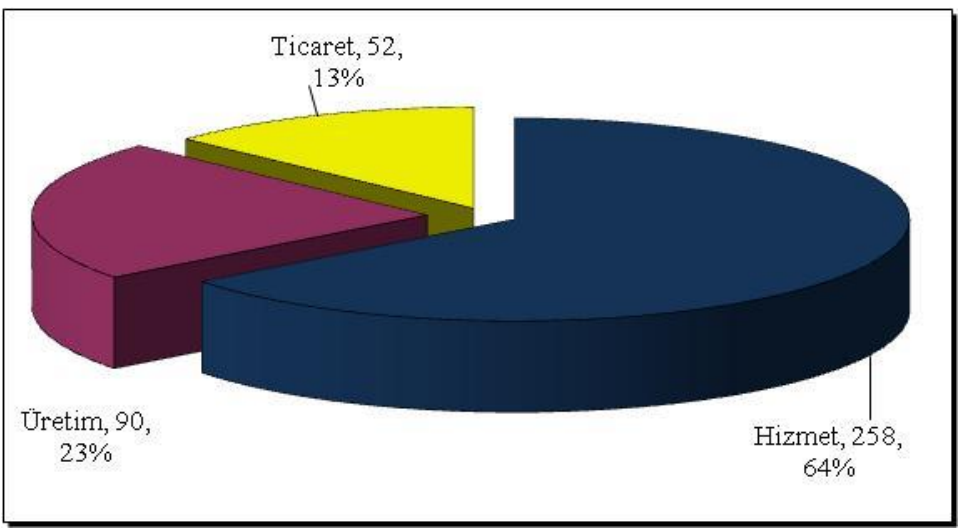


Analiz sonucunda kadınların hizmet sektöründe erkeklerle eşit oranda dağgldığg, üretim ve ticarette ise daha düşük sayıda oldukları görülmektedir.

IV.C. Girişimeilerin İş Hayatına ve İş Kurmaya Yönelik Tecrübeleri

Girişimcilikte başarıyı yakalamanın en önemli şartlarından birisinin iş tecrübesi ve özellikle kurulacak iş ile ilgili deneyimin olmasıdır. Söz konusu durum şirketlerin devamlılı̆g ve ekonomiye katkılarının artmasında da etkilidir. 400 kişilik grup içinde 331 girişimci adayının iş tecrübesi olup, iş tecrübesi olan kadınlar iş tecrübesi olan erkeklere oranla daha az sayıdadır. Temmuz 2013'de 156 girişimci adayı üzerinde yapılan bir başka araştırmaya göre ise katılımcılar ortalama 3.4 y1llık tecrübeye sahip iken, yüzde 57'si 1 veya 2 yıllık, yüzde 8's ise 10 yılın üzerinde bir tecrübeye sahiptir. (BIC Angel Investment, 2013).

Grafik 5'in de gösterdiği gibi girişimci adaylarının çok önemli bir bölümü ilk defa iş kuracaktır. Bu durum, içinde yönetim ve sürdürülebilirlik konusunda başarısızlık yaşanması tehlikesini de barındırmaktadır.

Grafik 5. Girişimcilerin İș Kurma Tecrübeleri

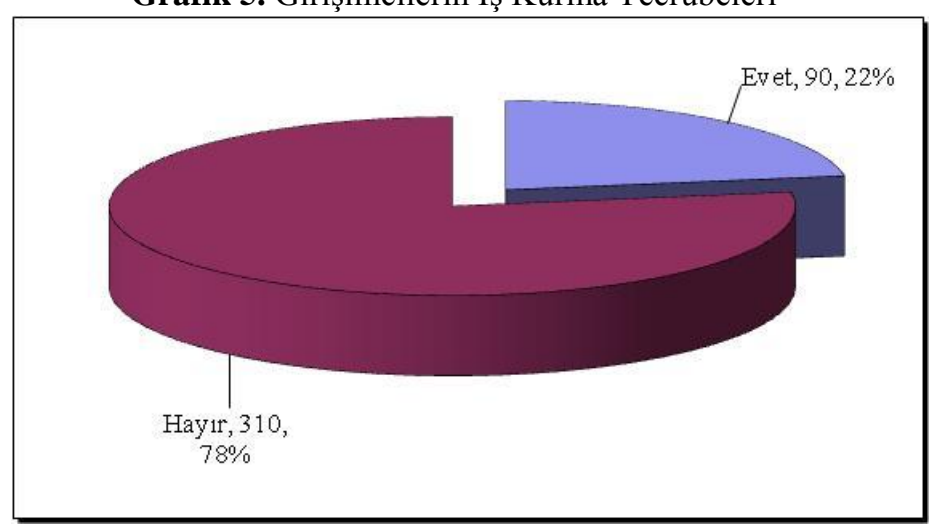

Diğer taraftan iş kurma açısından da erkeklerin kadınlara göre daha deneyimli oldukları gözlenmiştir. Daha önce iş kurmuş olan 90 girişimci adayının içinde kadınların payı yüzde 30 iken erkeklerin payı yüzde 70 seviyesindedir. İş kurmayan 310 kişinin dağılımında ise kadın erkek oranı hemen hemen birbirine eşittir.

\section{IV.D. Ortaklık Kültürü}

Ülkemizde işletmelerin yapıları incelendiğinde; ortaklık kültürünün çok fazla geliştiğini söyleyebilmek mümkün değildir. Türkiye'deki işletmelerin büyük bir çoğunluğunu gerek ekonomik nedenler gerekse ortaklık kültürünün gelişmemesi nedeniyle şahıs şirketleri oluşturmaktadır. 2010 yılında ferdi mülkiyet olan girişimlerin payı yüzde 49.3, limited şirket olan girişimlerin payı ise yüzde 28.9 olarak hesaplanmıştır (TÜİK, 2013). Ortaklık konusunda söz konusu düşünce ve geleneğin girişimci adaylarında da devam ettiği 400 kişiden 314'ünün ortak istemediğini beyan etmesiyle görülmektedir. Söz konusu düşünce doğrultusunda kadın erkek oranları da çok yakın seviyelerdedir. 
Grafik 6. Girişimcilerde Deneyim, İş Kurma ve Ortaklık İlişkisi

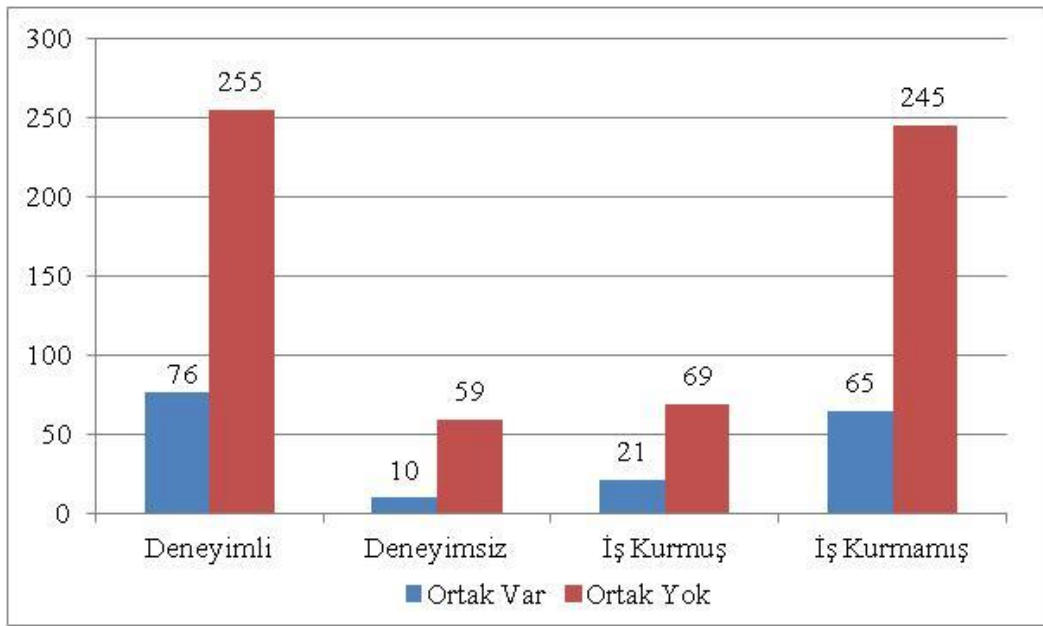

Diğer taraftan Grafik 6'da da görüldüğü üzere deneyimli/deneyimsiz ya da daha önce iş kurmuş/iş kurmamış ayrımı olmaksızın girişimci adayları kuracakları şirketlerin yüzde 100 oranında kendilerine ait olmasını tercih etmektedirler. Türkiye'deki ortaklık konusuna bu şekilde mesafeli duruş özellikle devlet ve özel kuruluşların bölgelerde gerçekleştirmeye çalıştıkları kümelenme çalışmalarının da başarısı ve devamlılığının önünde bir bariyer oluşturmaktadır.

\section{IV.E. İstihdam Yaratma Potansiyeli}

Girişimcilik istihdam yaratma özelliği nedeniyle ekonomiler açısından büyük değer taşımaktadır. İş kayıtlarında 2008 yılında yeni doğan işveren girişimlerin istihdam yaratma oranı yüzde 10.7 iken söz konusu oran 2009 yılında yüzde 6.7, 2010 yılında yüzde 2.5 olarak açıklanmıştır (TÜİK, 2013). 400 kişilik grubun iş kurmaları halinde yaratacakları istihdam toplamı 1,509 kişi olarak hesaplanmıştır. Kendilerinin de iş sahibi olacakları düşünüldüğünde toplam rakam yaklaşık 1,900 kişiye ulaşmaktadır. Genel ortalamaya bakıldığında her şirketin 5 kişilik istihdam yaratma potansiyeli taşıdığ1 görülmektedir. KOSGEB 2011 2013 yılları arasında yaklaşık 10,500 girişimciye destek vermiştir. Söz konusu ortalama ile bu sayı birleştirildiğinde en az 10,500 en fazla 50,000 kişinin iş sahibi olduğu saptanmaktadır. Grafik 7'de gösterildiği gibi girişim başına ortalama istihdam yaklaşık 5 kişi olup, yoğunlaşma söz konusu değerin altında oluşmaktadır. Türkiye Girişimcilik Araştırması'nda saptanan rakam ise yaklaşık 4 kişidir (GfK, 2011). 
Grafik 7. Girişimcilerin İstihdam Rakamları

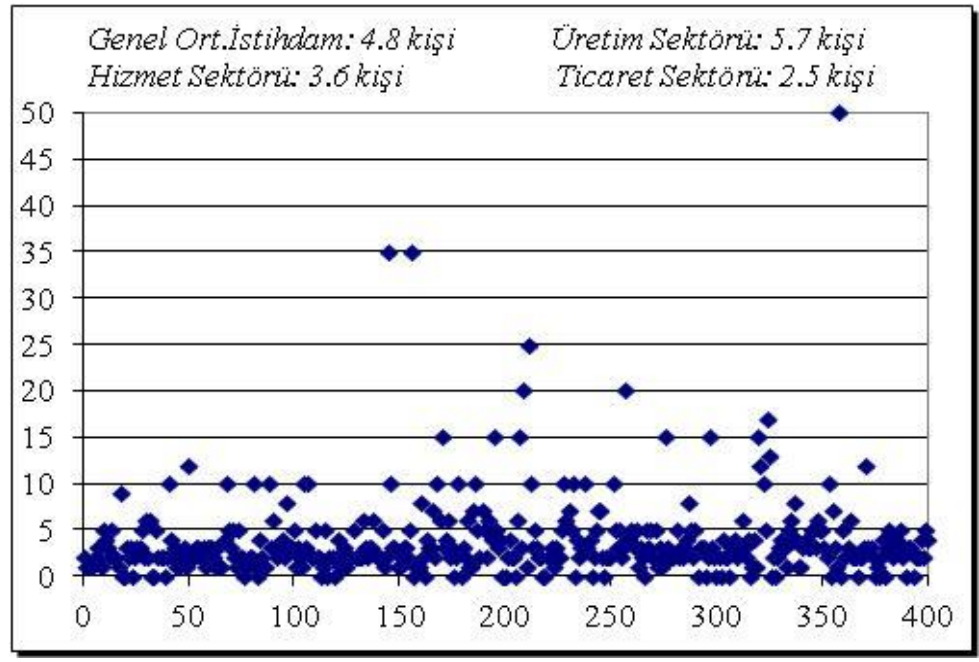

2008 yılında Türkiye'de KOBİ'lerde ortalama çalışan sayısı 3 olup, söz konusu ortalama ticaret ve hizmetler sektörlerinde 2, üretim sektöründe 6 kişidir (KOSGEB, 2011b: s.31). 400 kişilik grubun verdiği cevaplardan 2013 yılına ait sonuç ile 2008 yılında Türkiye'ye ait rakamlar arasında bir paralellik gözlenmektedir.

\section{IV.F. Sermaye Birikimi, Sermaye İhtiyacı ve Finansal Kaynaklar}

Tüm dünyada olduğu gibi Türkiye'de de hem girişimcilerin hem de KOBİ'lerin temel sorunlarının başında finansal kaynaklara ulaşmada zorluk ve yetersizlik gelmektedir. Dünyanın en gelişmiş ekonomilerinden ABD’nde bile çok fazla finansman modeli bulunmasına rağmen girişimciler ve KOBI'ler finansal yetersizlik ile mücadele etmektedirler. Söz konusu durum her ne kadar finans sektöründe yeni ürünler ve uygulamalar başlamış olsa da Türkiye için de geçerliliğini korumaktadır. Türkiye'de bankacılık sektörünün tüm gelişmelere rağmen özellikle teminat konusundan kaynaklanan sorunlara alternatif çözümler bulamayışı, iş melekleri kavramının yakın dönemlerde uygulamaya geçmesi, girişim sermayesi şirketlerinin ise riskin göreli olarak düşüklüğü ve karlılığın yüksekliği nedeniyle daha çok orta ve büyük ölçekli şirketlerle çalışma isteği söz konusu girişimcilerin başlangıç sermayesi bulmaları sırasında zorluklar yaşamasına neden olmaktadır. "Kendi işinizi kurmanın önündeki en büyük engel nedir?" sorusuna girişimcilerin yüzde 70'i "başlangıç sermayelerinin olmaması", "devlet desteği bulunmaması" ve "bilgi eksikliği" yanıtını vermekte (GfK, 2010), her üç kişiden biri kişisel bilgi ve becerilerinin girişimcilik için yeterli olmadığını düşünmektedir (GfK, 2011).

400 kişilik grubun verdiği cevaplar çerçevesinde girişimci adaylarının iş kurmaları ile ilgili ihtiyaçları olan sermaye miktarı ortalama olarak 70,801 TL'dir. 
400 kişilik grupta 200,000 TL'nin üzerinde sermaye ihtiyacı olan 10 girişimci adayının dışında kalan grubun ortalaması ise 64,355 TL'dir. Grafik 8'de de gösterildiği gibi hizmetler ve ticaret sektörlerinde yaklaşık değerler mevcut iken üretim sektöründe sermaye ihtiyacı diğer sektörlere oranla daha yüksektir. Diğer taraftan sermaye ihtiyacı miktarındaki yoğunlaşma 50,000 TL seviyesindedir.

Grafik 8. Girişimcilerin Sermaye İhtiyacı

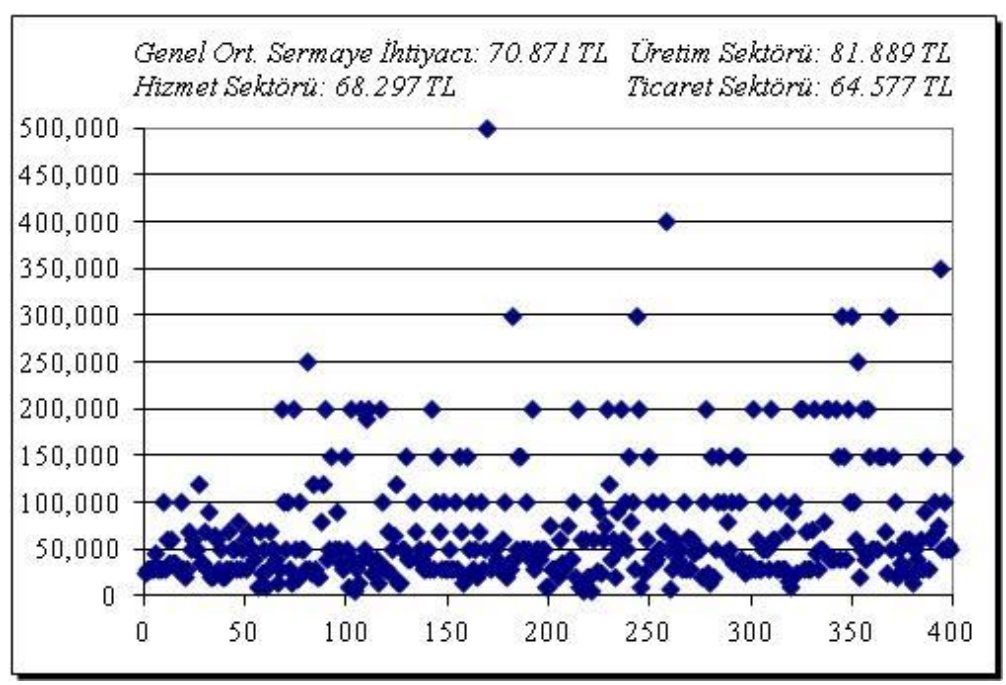

Sermaye ihtiyacının kadın erkek bazlı ayrımlarında ise ortalama sermaye ihtiyacı kadın girişimcilerde 66,126 TL iken erkek girişimcilerde 75,038 TL olarak hesaplanmıştır.

Türkiye'de KOSGEB'in girişimciler için uyguladığ 1 "Girişimcilik Desteği”nin miktarıyla girişimcilerin ihtiyacı olduğu tespit edilen miktarlar arasında da bu bağlamda paralellik bulunmaktadır. KOSGEB'in Girişimcilik Desteği, 30,000 TL'lik kısmı hibe, 70,000 TL'lik kısmı ise 24 ayı geri ödemesiz olmak üzere 48 ay vadeli 0 faiz oranlı banka kredisinden oluşmakta ve KOSGEB banka faizleri konusunda yine girişimcilere destek sağlamaktadır. Bununla birlikte, her ne kadar kadın girişimcilerin ihtiyacı olan miktar erkeklere oranla daha düşük olsa da kadınların iş hayatına dahil edilmesi ve kadın girişimciliğin gelişmesi amacıyla söz konusu desteğin miktarında olmamakla birlikte oranlarında pozitif ayrımcılık yapılmıştır. Yine benzer şekilde özürlü kişiler için de destek oranları kadınlarla eşit tutulmuştur. Diğer taraftan kalkınmada geri kalmış bölgelerin destek oranları ile kalkınmış bölgelerin oranları arasında da 1,000 baz puanlık fark bulunmaktadır.

400 kişilik gruptan edinilen bilgiler çerçevesinde toplamda 100,000 TL'ye ulaşan Girişimcilik Desteği yeni iş kuracak girişimci adayları için birçok problemi çözebilecek niteliktedir. Girişimcilik Desteği'nin miktarları, bölgelere ve kadın erkek ayrımına göre düzenlemeleri ve girişimcilerin harcamaları gereken miktarlar Tablo 2'de gösterilmiştir. 
Tablo 2. KOSGEB Girişimcilik Desteği, Girişimcinin Harcaması Gereken Tutarlar

\begin{tabular}{|c|c|c|c|c|c|}
\hline \multirow[b]{2}{*}{ Destekler } & \multirow[b]{2}{*}{ Üst Sinur } & \multicolumn{2}{|c|}{ I. \& II. Bölgeler } & \multicolumn{2}{|c|}{ III. IV. V. \& VI. Bölgeler } \\
\hline & & Erkek (\%60) & Kadun \& Özürlü (\%70) & Erkek $(\% 70)$ & Kadun \& Özürlü (\%80) \\
\hline İ̧lettme Kuruluş Desteği & 3.000 & 5.000 & 4.286 & 4.286 & 3.750 \\
\hline Kuruluş Dönemi Makine, Teçhizat, Ofis Donanimm ve Yazlim Desteğg & 15.000 & 25.000 & 21.429 & 21.429 & 18.750 \\
\hline Işletme Giderleri Desteğ (12-24 ay içinde aylk $1.000 \mathrm{TL}$ ) & 12.000 & 20.000 & 17.143 & 17.143 & 15.000 \\
\hline Sabit Yatrim Desteği (24 ay geri ödemesiz 48 ay faizsiz) & 70.000 & 116.667 & 100.000 & 100.000 & 87.500 \\
\hline Toplam & 100.000 & 166.667 & 142.857 & 142.857 & 125.000 \\
\hline 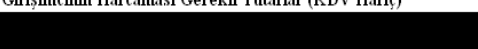 & & \multicolumn{2}{|c|}{ I. \& II. Bölgeler } & \multicolumn{2}{|c|}{ III. IV. V. \& VI. Bölgeler } \\
\hline Destekler & Üst Sinr & Erkek (\%60) & Kadun \& Özürlü (\%70) & Erkek $(\% 70)$ & Kadun \& Özürlü (\%80) \\
\hline Işletme Kunduş Desteğj & 3.000 & 2.000 & 1.286 & 1.286 & 750 \\
\hline Kuruluṣ Dönemi Makine, Teçhizat, Ofis Donantm ve Yazlim Desteğj & 15.000 & 10.000 & 6.429 & 6.429 & 3.750 \\
\hline Işletme Giderleri Desteğ (12-24 ay içinde aylik $1.000 \mathrm{TL}$ ) & 12.000 & 8.000 & 5.143 & 5.143 & 3.000 \\
\hline Sabit Yatrrm Desteği (24 ay geri ödemesiz 48 ay faizsiz) & 70.000 & 46.667 & 30.000 & 30.000 & 17.500 \\
\hline Topham & 100.000 & 66.667 & 42.857 & 42.857 & 25.000 \\
\hline & & \multicolumn{2}{|c|}{ I. \& II. Bölgeler } & \multicolumn{2}{|c|}{ III. IV. V. \& VI. Bölgeler } \\
\hline Destekler & Üst Surr & Erkek (\%60) & Kadun \& Özürlü (\%70) & Erkek $(\% 70)$ & Kadun \& Özürlü (\%80) \\
\hline İ̧̧letme Kuruluş Desteği & 3.000 & 5.000 & 4.286 & 4.286 & 3.750 \\
\hline Kuruluş Dönemi Makine, Teçhizat, Ofis Donanım ve Yazilm Desteğg & 15.000 & 29.500 & 25.286 & 25.286 & 22.125 \\
\hline Işletme Giderleri Desteğ (12-24 ay içinde aylk $1.000 \mathrm{TL}$ ) & 12.000 & 23.600 & 20.229 & 20.229 & 17.700 \\
\hline Sabit Yatrrm Desteği (24 ay geri ödemesiz 48 ay faizsiz) & 70.000 & 137.667 & 118.000 & 118.000 & 103.250 \\
\hline Toplam & 100.000 & 195.767 & 167.800 & 167.800 & 146.825 \\
\hline 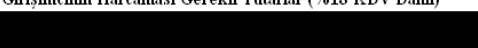 & & \multicolumn{2}{|c|}{ I. \& II. Bölgeler } & \multicolumn{2}{|c|}{ III. IV. V. \& VI. Bölgeler } \\
\hline Destekler & Üst Sinur & Erkek $(\% 60)$ & Kadun \& Özürlï (\%70) & Erkek (\%70) & Kadun \& Özürlü (\%80) \\
\hline İ̧sletme Kuruluş Desteği & 3.000 & 2.000 & 1.286 & 1.286 & 750 \\
\hline Kuruluş Dönemi Makine, Teçhizat, Ofis Donanım ve Yazlim Desteği & 15.000 & 14.500 & 10.286 & 10.286 & 7.125 \\
\hline Işletme Giderleri Desteği (12-24 ay içinde aylk $1.000 \mathrm{TL}$ ) & 12.000 & 11.600 & 8.229 & 8.229 & 5.700 \\
\hline Sabit Yatrrm Desteği (24 ay geri ödemesiz 48 ay faizsiz) & 70.000 & 67.667 & 48.000 & 48.000 & 33.250 \\
\hline Toplam & 100.000 & 95.767 & 67.800 & 67.800 & 46.825 \\
\hline
\end{tabular}

Kaynak: KOSGEB, Toksoy ve Sönmez, (2013)

Girişimci adaylarının söz konusu desteklerden faydalanabilmeleri için öncelikle Uygulamalı Girişimcilik Eğitimi’ni tamamlamış olmaları zorunluluğu bulunmaktadır. Eğitimi tamamladıktan sonra, en az yüzde 30 ortaklık oranında pay sahibi oldukları yeni bir şirket kurmaları ve yapacakları tüm harcamaları da beyan ettikleri İş Planları'nı KOSGEB yöneticilerinden oluşan Kurul'a onaylatmalıdırlar. Ancak iş planında gösterilmiş ve KOSGEB tarafından onaylanmış harcamalarına ait hibe ve desteklerden yararlanabilmeleri mümkündür. 2011 yılında yaklaşık 2,409 yeni işletme 2012 yılında 4,500 ve 2013 yılının ilk yarısında 3,580 işletme (KOSGEB, 2013b: 2) yeni girişimcilik desteğinden faydalanmış olup, söz konusu rakamlar içinde kadın girişimcilerin kurduğu işletme sayısı sırasıyla 1,621 ve 1,750'dir (KOSGEB, 2013a: 18). 2013 yılının ilk 6 ayında işletmelere verilen destek tutarı ise 27,805,642 TL (KOSGEB, 2013b: 2) olup, işletme başına ortalama 7,767 TL'lik destek sağlanmıştır. Özetle üç yıla yakın bir süre içinde KOSGEB'in girişimcilik eğitimlerini Türkiye çapında yaklaşık 120,000'in üzerinde girişimci adayı tamamlamış ve adayların yaklaşık 10,500'ü işletmesini kurarak KOSGEB'in desteklerinden faydalanmıştır. 
400 kişilik grubun tamamı KOSGEB Girişimcilik Desteği'nden faydalanacağını beyan etmekle birlikte, KOSGEB'in karşılamadığı harcamaları için başvuracakları kaynakları farklı şekillerde göstermişlerdir.

Grafik 8. Girişimcilerin Başlangıç Sermayesi Kaynakları

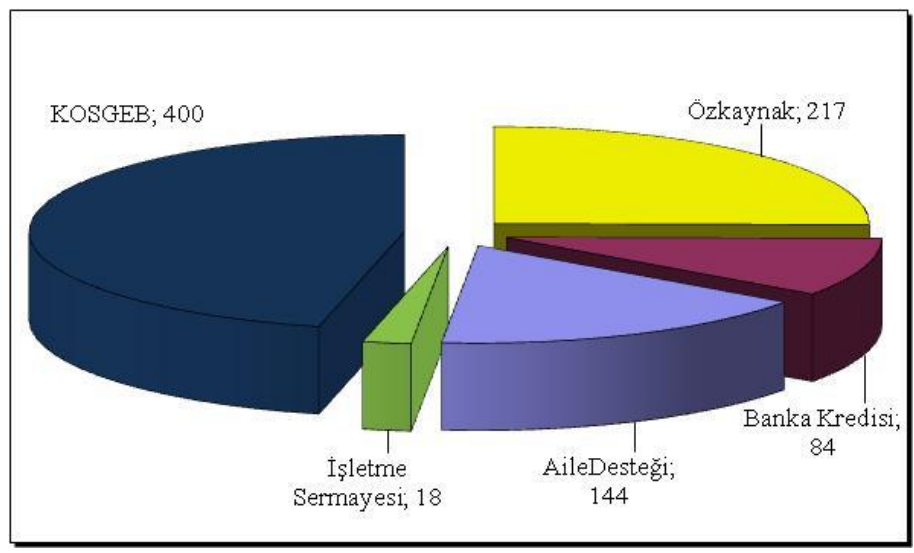

Grafik 8'de gösterilen kaynaklardan sadece birini ya da ayn1 anda birkaçını kullanma durumlarından dolayı toplam içindeki oranlar verilmemiştir. Özellikle teminat sorunu nedeniyle banka kredisi kendi kaynakları ve aile desteğinin ardından gelmektedir.

\section{IV.G. İnternet Kullanımı ve İletişim}

400 kişilik girişimci adayı üzerinden yapılan çalışmada tüm girişimcilerin cep telefonuna 356 girişimcinin de e-posta adresine sahip oldukları gözlemlenmiştir. $\mathrm{Bu}$ durum, genel anlamda internet üzerinden haberleşme konusunda girişimcilerle herhangi bir sorun yaşanmayacağını göstermektedir. Diğer taraftan hotmail ve gmail uzantılı adreslerin toplam içindeki oranlar sırasıyla yüzde 48.5 ve yüzde 30 olup, toplamda yüzde 78.5 gibi ciddi bir ağırlı̆̆a sahiptir.

Cep telefonu şirketi olarak büyük oranın yaklaşık yüzde 62 ile Turkcell'e ait olduğu saptanmıştır. Bununla birlikte, söz konusu durum tüm şirketler için geçerli olsa da aynı telefon numarası ile farklı bir şirketin müşterisi olma ihtimali de göz önünde bulundurulmalıdır.

Grafik 9. Girişimcilerin GSM Hattı Tercihi

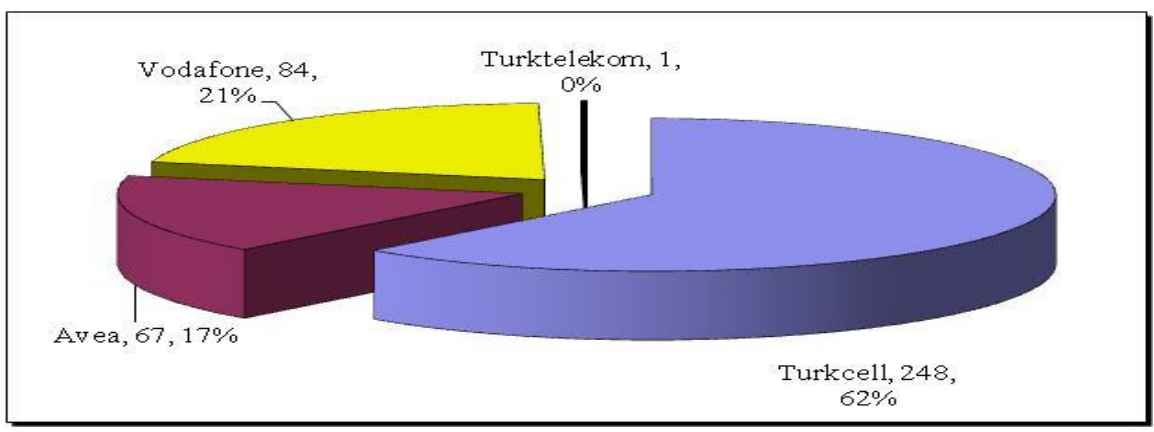


Cep telefonu kullanımının yaygınlığı özellikle haberleşmede kısa mesaj kullanımı açısından da önemli bir ayrıntıdır.

\section{SONUC}

Girişimcilik günümüzde dünya ekonomileri için olduğu kadar Türkiye ekonomisi için de gelişmenin ve yeni değerler yaratmanın, sektörler arası işbirliğinin artışının anahtarı olarak gösterilmektedir. Bu nedenle girişimcilerin önündeki engelleri kaldırmak ve fikirlerinin ekonomiye katılmasını ve ticarileşebilmesi sağlamak amacıyla farklı çalışmalar yapılmaktadır. Türkiye'de 1990'larda başlayan ve 2000'li yıllarda hız kazanan girişimcilik çalışmaları da son yıllarda hedeflerine ulaşmaya başlamış ve yeni girişimler piyasalarda yerlerini almıştır. Mayıs - Ağustos 2013 aylarında KOSGEB Uygulamalı Girişimcilik Eğitimi'ni tamamlayan 400 girişimci adayı ile yapılan çalışma sonucunda;

- girişimcilerin eğitim seviyelerinin yükselmeye başladığı,

- girişimcilik yaş aralığında yoğunluğun 30-44 yaş arasında olduğu,

- kadınların girişimciliğe olan ilgilerinin giderek arttığı,

- çoğunluğun iş tecrübesinin ve iş tecrübesine sahip kadınların iş tecrübesine sahip erkeklere oranla daha az sayıda olduğu,

- girişimci adaylarının yüzde 90'ının ilk defa iş kuracağı ve daha önce iş kurmuş olan girişimci adayları içinde kadınların payının erkeklerin payının yarısından az olduğu,

- ortaklık konusunda Türk düşünce ve geleneğinin girişimci adaylarında da devam ettiği ve büyük bir çoğunluğun ortak istemediği,

- genel ortalamada her şirketin 5 kişilik istihdam yaratma potansiyeli taşıdığı,

- başlangıç sermayesi ihtiyacındaki yoğunlaşmanın 50,000 TL ve altında kaldığı ve kadınlarda sermaye ihtiyacının erkeklere göre daha az olduğu,

- sermaye ihtiyaçlarını KOSGEB desteklerinin yanı sıra öncelikle özkaynakları ve aile yardımı sonrasında da banka kredileri ile çözmeyi planladıkları,

- hemen hepsinin e-posta adresine ve cep telefonu numarasina sahip olduğu şeklinde bulgular elde edilmiştir.

\section{KAYNAKÇA}

BERRY, Tim, (Haziran 2007) "Market Fit is Critical", http://timberry.bplans.com/2007/06/marketfit-is-c.html (15/01/2014)

BIC ANGEL INVESTMENT, (Temmuz 2013), “Türkiye Girişimcilik Araştırması, 2013”, http://www.webrazzi.com/2013/07/17/bic-angel-investment-girisimcilik-arastirmasiinfografik/ (08/07/2013)

BİLIM SANAYİ VE TEKNOLOJİ BAKANLIĞI, (2010), “Türkiye Sanayi Stratejisi Belgesi 2011 2014 (AB Üyeliğine Doğru)", 22-42.

ÇETINDAMAR, Dilek, (2002), “Türkiye'de Girişimcilik”, TÜSİAD Yayınları, 33.

GfK, (2011), "Girişimcilik Araştırması", https://www.kobilersizinicin.com/turkiyedegirisimcilik.aspx (12/01/2014)

GfK, (2010), "Girişimcilik Araştırması", http://www.dogrudansatisdunyasi.com/?p=24 (12/01/2014)

HISRICH, R. ve PETERS M. (2001), "Entrepreneurship", 5th Edition, McGraw Hill Higher.

KALKINMA BAKANLIĞI, (2013a), "Onuncu Kalkınma Planı (2014 - 2018)", 35-100.

KALKINMA BAKANLIĞI, (2013b), "Orta Vadeli Program 2014 - 2016”, 46.

KALKINMA BAKANLIĞI, (2012), "Orta Vadeli Program 2013 - 2015”, 38. 
KALKINMA BAKANLIĞI, (2006), "Dokuzuncu Kalkınma Planı (2007 - 2013)", 40-82.

KOSGEB, (2013a), "2013 Y1lı Performans Programı", 13-18.

KOSGEB, (2013b), "2013 Y1lı İlk Altı Aylık Kurumsal Mali Durum ve Beklentiler Raporu”, 2.

KOSGEB, (2011a), "2011-2015 KOSGEB Stratejik Planı", 9-41.

KOSGEB, (2011b), "KOBİ Stratejisi ve Eylem Planı 2011-2013”, 58.

ROBINSON Joy, (Ocak 2014), "The 7 Traits of Successful Entrepreneurs", http://www.entrepreneur.com/article/230350, (12/01/2014)

SCHUMPETER, Joseph A. (1911), "The Theory of Economic Development. An Inquiry into Profits, Capital, Credit, Interest, and the Business Cycle." Translated by R. Opie, and Published by Oxford University Press (1963), 66.

SHANE, Scott, (Kasim 2011), "Who Counts As an Entrepreneur? (Opinion)", http://www.entrepreneur.com/article/230350 (15/01/2014)

http://www.girisimhaber.com/post/2011/12/24/Turkiyede-Yukselen-Deger-Girisimcilik.aspx $(12 / 12 / 2013)$

TOKSOY, Andaç, SÖNMEZ Asuman, (2013), "KOSGEB Girişimcilik Programı ve Uygulamalı Girişimcilik Eğitimleri Alan Kişiler Üzerinde Bir Araştırma”, Uluslar arası Girişimcilik ve Kariyer Sempozyumu, Sempozyum Kitab1, 333-351

TÜİK, (2013), "Girişimcilik, 2010 Girişimcilik istatistikleri yayımlandı", Haber Bülteni, Sayı: 13664.

TÜSİAD, (2003), “’Türkiye'de Girişimcilik” Özet Bulgular”, Basın Bülteni, TS/BAS/03-018, s.8.

"Türkiye'de Yükselen Değer Girişimcilik", (Aralık 2011), http://www.girisimhaber.com/post/2011/12/24/Turkiyede-Yukselen-DegerGirisimcilik.aspx (12/12/2013).

“Türkiye'nin En Hızlı Büyüyen 100 Şirketi açıklandı" (Aralık 2013), http://www.tobb.org.tr/Sayfalar/Detay.php?rid=19045\&lst=MansetListesi (12/12/2013).

http://turtleinvestor888.blogspot.com/2009/07/entrepreneurship-requires-four-areas-of.html (15/01/2014)

https://www.kobilersizinicin.com/turkiyede-girisimcilik.aspx (15/01/2014) 